\title{
Patients with advanced periodontal disease before intensity-modulated radiation therapy are prone to develop bone healing problems: a 2-year prospective follow-up study
}

\author{
Jennifer M. Schuurhuis ${ }^{1}$ - Monique A. Stokman ${ }^{1,2}$ • Max J. H. Witjes ${ }^{1}$. \\ Harry Reintsema ${ }^{1}$ - Johannes A. Langendijk ${ }^{2} \cdot$ Arjan Vissink $^{1}$. \\ Frederik K. L. Spijkervet ${ }^{1}$
}

Received: 19 January 2017 / Accepted: 16 October 2017 /Published online: 31 October 2017

(C) The Author(s) 2017. This article is an open access publication

\begin{abstract}
Purpose Intensity-modulated radiation therapy (IMRT) has changed radiation treatment of head and neck cancer (HNC). However, it is still unclear if and how IMRT changes oral morbidity outcomes. In this prospective study, we assessed the outcome of reducing post-IMRT sequelae by means of pre-radiation dental screening and eliminating oral foci.

Methods All consecutive dentate patients $>18$ years, diagnosed with primary oral or oropharyngeal carcinoma, referred for pre-treatment dental screening between May 2011 and May 2013, were included and followed for 2 years. Patients were treated with IMRT or IMRT with chemotherapy (CHIMRT). Dental screening data, demographic data, and data on oral sequelae during follow-up were recorded. Diagnosed oral foci were treated before start of the radiation therapy.

Results Oral foci were found in 44/56 (79\%) patients, consisting predominantly of periodontal breakdown. Bone healing problems after radiotherapy occurred more often in patients with periodontal pockets $\geq 6 \mathrm{~mm}$ at baseline (19 vs. $4 \%$ in patients with pockets $<6 \mathrm{~mm}$ ). Osteoradionecrosis developed in 4/56 patients ( $7 \%$ ) during follow-up. In line with this observation, multiple logistic regression analysis showed
\end{abstract}

Frederik K. L. Spijkervet

f.k.1.spijkervet@umcg.nl

1 Department of Oral and Maxillofacial Surgery, University of Groningen, University Medical Center Groningen, Huispostcode BB70, P.O. Box 30001, 9700 RB Groningen, the Netherlands

2 Department of Radiation Oncology, University of Groningen, University Medical Center Groningen, P.O. Box 30001, 9700 RB Groningen, the Netherlands that the periodontal inflamed surface area, which is higher in patients with more severe periodontal disease, predicted that a patient has a higher risk on developing osteoradionecrosis or bone healing problems $(p=0.028)$.

Conclusions Patients with severe periodontal disease before IMRT/CHIMRT are more prone to develop bone healing problems post-radiotherapy.

Keywords Head and neck cancer · Intensity-modulated radiotherapy $\cdot$ Chemoradiotherapy $\cdot$ Dental focal infection . Osteoradionecrosis $\cdot$ Periodontitis

\section{Introduction}

Head and neck cancer (HNC) patients treated by radiotherapy are at risk of developing severe oral sequelae. Periodontal disease, an inflammatory disease affecting the tissues surrounding the teeth resulting in inflammation of the gums and loss of bone adjacent to the affect teeth, and radiationassociated dental caries may require dental extractions and consequently result in an increased risk of developing osteoradionecrosis (ORN) of the jaw [1-4]. ORN is radiation-induced destruction of the bone. ORN is difficult to treat, not self-limiting, and may require extensive invasive surgery and/or adjuvant treatment with hyperbaric oxygen (HBO). Hypovascularity and hypocellularity of irradiated tissues are considered the predominant underlying pathophysiologic mechanisms, which have low reparative ability $[5,6]$. The majority of ORN cases develop within 3 years after radiotherapy [7].

Risk factors for developing ORN include post-irradiation extractions [1], periodontal attachment loss/periodontitis [2], 
oral surgical interventions [8], and poor dental status [9]. To prevent oral morbidity after radiotherapy, in particular ORN, pre-radiation dental screening is commonly performed to locate and eliminate oral foci, although the efficacy of these interventions is unclear [3]. An oral focus is defined as a pathologic process in the oral cavity that does not cause major problems in healthy individuals, but may lead to severe local or systemic inflammation under certain circumstances [1, 10].

During the last decade, treatment of $\mathrm{HNC}$ has changed substantially, particularly due to the introduction of intensity-modulated radiation therapy (IMRT) and concomitant chemoradiation [11]. The effects of IMRT on oral tissues and jaw bone in particular are not yet clearly understood. IMRT results in less reduction of salivary flow due to sparing of the parotid and/ or submandibular glands [12]. However, dose redistribution resulting from salivary gland sparing may lead to higher doses to other tissues in the radiation field, in particular to the oral mucosa, which can result in "beam path toxicities" [13]. These potentially higher doses to jaw bone and oral tissues entail a higher risk of developing ORN post-radiotherapy [6].

Current pre-radiation dental screening protocols are based on conventional radiotherapy and require an update to take account of the IMRT effects. We therefore conducted a prospective 2-year follow-up cohort study to assess the outcome of pre-radiation dental screening and elimination of oral foci in HNC patients treated with IMRT. Results were compared to those of historical controls treated with three-dimensional conformal radiation therapy [2].

\section{Methods}

\section{Patients}

All consecutive dentate or partially dentate patients $>18$ years, diagnosed with primary oral or oropharyngeal carcinoma, referred to the University Medical Center Groningen (UMCG), the Netherlands, for pre-treatment dental screening between May 2011 and May 2013, were included if IMRT to the head and neck region was part of the treatment plan. Patients who had undergone previous oncologic treatment (surgery and/or radiotherapy and/or chemotherapy) to this region were excluded as well as patients with unknown primary or parotid gland tumors. A standardized follow-up of 2 years' postoncologic treatment related to oral and dental morbidity was completed (JMS). Written informed consent was obtained from all patients. The medical ethical committee of the UMCG approved the study (METC 2012/091).

\section{Dental screening}

All patients were evaluated before their oncologic treatment as part of routine clinical practice by means of oral and dental screening, including radiographic examination [14]. Plaque and bleeding scores were assessed as a percentage of the total number of sites with plaque respectively bleeding on probing. To quantify periodontal disease, the periodontal inflamed surface area (PISA) was used [15]. Patients were asked about their smoking and drinking habits. Self-reported smoking options were "current smoker," "past smoker," or "never smoked." Self-reported alcohol consumption options were "never drink alcohol" or "drink alcohol."

All data obtained at baseline and follow-up visits (Table 1) were collected in pre-determined order and recorded using a standardized study form.

\section{IMRT}

All included patients were subjected to definitive primary or postoperative IMRT or definitive primary or postoperative chemoradiation (CHIMRT). Patients treated with concomitant CHIMRT were irradiated with a conventional fractionation schedule (2 Gy per fraction, five times per week up to $70 \mathrm{~Gy}$ in 7 weeks). In case of primary radiotherapy of tumors considered ineligible for CHIMRT, an accelerated schedule (six times per week) with concomitant boost technique was used, either or not combined with cetuximab. IMRT treatments attempted to spare the parotid glands without compromising dose to target volumes. In general, 7-field equidistant, non-opposing beams were applied. All IMRT treatments applied a simultaneous integrated boost. Most patients received bilateral elective irradiation of the neck nodes to a total dose of $54.25 \mathrm{~Gy}$, in fractions of 1.55 Gy. Primary tumor and pathological lymph nodes were treated to a total dose of 70 Gy, in 2 Gy fractions.

If applied, chemotherapy was given concurrently with fractionated IMRT and consisted of Carboplatin on day 1 (300$350 \mathrm{mg} / \mathrm{m}^{2}$ in $30 \mathrm{~min}$ intravenously) and 5-fluorouracil (5FU) from day 1 to 4 by continuous infusion $\left(600 \mathrm{mg} / \mathrm{m}^{2} /\right.$ $24 \mathrm{~h}$ ), consisting of three courses given with an interval of 3 weeks. Postoperative chemotherapy consisted of $6 \times 50 \mathrm{mg}$ Cisplatin weekly. When chemotherapy was considered to be infeasible, patients were treated with cetuximab using a loading dose of $400 \mathrm{mg} / \mathrm{m}^{2} 1$ week prior to radiotherapy and a weekly dose of $250 \mathrm{mg} / \mathrm{m}^{2}$ during radiotherapy.

\section{Treatment of oral foci}

Before onset of IMRT or CHIMRT, oral foci were eliminated (Table 2), if teeth related to the foci were within the radiation field receiving a cumulative dose $>40 \mathrm{~Gy}$. An oral focus was defined as follows [3]: 
- $\quad$ severe dental caries in which excavation may lead to pulpal exposure;

- $\quad$ severe periodontal disease, defined as pockets on probing $\geq 6 \mathrm{~mm}$, furcation $\geq$ grade 1 , mobility $>$ grade 1 , gingival recession $\geq 6 \mathrm{~mm}$, and especially a combination of these periodontal problems;

- non-restorable teeth with large restorations, especially those extending beyond the gum line or with root caries, or those with severe erosion or abrasion;

- $\quad$ periapical pathosis and non-vital teeth;

- impacted, partially impacted, or partially erupted teeth not fully covered by bone or showing radiolucency;

- cysts and other radiographic abnormalities.

Dental pathology not defined as an oral focus was treated according to professional dental standards. Before the onset of IMRT or CHIMRT, patients were seen by a dental hygienist for dental prophylaxis and oral hygiene instructions.

\section{Oral care during radiotherapy}

During IMRT and CHIMRT, patients were seen daily (Monday to Friday) by a dental hygienist for spraying the oral cavity with saline according to standard protocol [16]. Instructions were given to continue normal daily oral care (tooth brushing and/or interdental cleaning) as long as possible, and to rinse the mouth with salt-baking soda solution at home, 8-10 times per day [14]. Dentate IMRT and CHIMRT patients received custom-made fluoride trays and were prescribed a neutral $1 \%$ sodium fluoride gel to be used every second day $[14,17,18]$.

\section{Follow-up}

Regular oncology follow-up visits to the oral and maxillofacial surgeon, dental hygienist, and/or hospital dentist were combined with visits to the researcher (JMS) (Table 1). Dental follow-up by the dental hygienist and hospital dentist is standard for IMRT and CHIMRT patients every 3-6 months, depending on the patient's needs, during at least 5 years after treatment. Oral sequelae during follow-up were recorded, including caries and restorative problems, periodontal disease, bone healing problems, and ORN. According to the prevailing definition, ORN is an area of exposed devitalized irradiated bone that fails to heal over a period of 3 months in the absence of local neoplastic disease [5, 19-21]. All other phenomena of a delayed bone healing, such as bone sequestration after radiation and areas with non-healing bone after tooth extraction less than 3 months, were defined as bone healing problems. Antibiotic prophylaxis was given in case of surgical intervention and, if the dose in the specific region of surgical treatment was $\geq 40$ Gy, application of HBO was considered depending on patient factors, such as smoking, general
Table 1 Overview of data collection in chronological order

\begin{tabular}{|c|c|c|c|c|}
\hline $\begin{array}{l}\text { Data collection and } \\
\text { sampling }\end{array}$ & $\begin{array}{l}\text { Dental } \\
\text { screening }\end{array}$ & $\begin{array}{l}\text { Before } \\
\text { onset of } \\
\text { IMRT or } \\
\text { CHIMRT }\end{array}$ & $\begin{array}{l}6 \text { weeks } \\
\text { after IMRT } \\
\text { or } \\
\text { CHIMRT }\end{array}$ & $\begin{array}{l}\text { Every } \\
6 \text { months } \\
\text { until end of } \\
\text { follow-up }\end{array}$ \\
\hline Panoramic X-ray & $X$ & & & $\mathrm{X}$ \\
\hline $\begin{array}{l}\text { General health and } \\
\text { medication }\end{array}$ & $\mathrm{X}$ & $\mathrm{X}$ & $\mathrm{X}$ & $\mathrm{X}$ \\
\hline Alcohol/Tobacco & $\mathrm{X}$ & $X$ & $\mathrm{X}$ & $\mathrm{X}$ \\
\hline Oral examination & $\mathrm{X}$ & $\mathrm{X}$ & $\mathrm{X}$ & $\mathrm{X}$ \\
\hline $\begin{array}{l}\text { Periodontal } \\
\text { examination } \\
\text { incl. plaque and } \\
\text { bleeding score }\end{array}$ & $\mathrm{X}$ & & & $\mathrm{X}$ \\
\hline
\end{tabular}

IMRT intensity modulated radiation therapy, CHIMRT IMRT with chemotherapy

health, and complexity of removal of affected teeth. Moreover, when oral sequelae occurred during follow-up and if they were within the radiation field ( $\geq 40 \mathrm{~Gy}$ ), all efforts were made to prevent tooth extraction. All data (dental screening and followup visits) were recorded using the standardized study form.

\section{Historical control group}

The historical control group consisted of 80 adult HNC patients who had been subjected to pre-radiation dental screening for oral foci. They received postoperative or primary curative three-dimensional conformal radiation therapy or chemoradiation, as part of primary cancer treatment for carcinoma in the oral cavity or oropharynx [2].

\section{Statistical analysis}

Data were analyzed using IBM SPSS Statistics 23.0 for Windows. Values of $p<0.05$ were considered significant. Testing for significance was done using Chi-square tests for binary data (developing ORN, having bone healing problems) and Kruskal-Wallis tests for quantitative data (PISA). The Wilcoxon signed rank test was used for comparing baseline PISA scores with followup data.

Age at dental screening, smoking and alcohol use at baseline, treatment applied for foci elimination, pocket depth $\geq 6 \mathrm{~mm}$, PISA score, T-stage, radiotherapy dose, conventional or accelerated radiotherapy, surgical treatment, and chemotherapy were explored for their predicted value influencing the development of ORN or bone healing problems at the follow up assessment with multiple logistic regression analysis. Variables that were significantly associated with the outcome variable $(p \leq 0.10)$ were entered in the logistic regression analyses. Variables not significantly contributing to the regression equation were removed $(p>0.10)$. 
Table 2 Assessment and treatment of oral foci within or outside the radiation field

\begin{tabular}{|c|c|c|}
\hline Assessed tooth problems & Treatment if cumulative dose $>40 \mathrm{~Gy}^{\mathrm{a}}$ & $\begin{array}{l}\text { Treatment if cumulative dose }<40 \text { Gy } \\
\text { or outside the radiation portal }^{\mathrm{a}}\end{array}$ \\
\hline Caries profunda & Tooth extraction & $\begin{array}{l}\text { Restoration, if necessary combined with } \\
\text { endodontic treatment, or tooth extraction }\end{array}$ \\
\hline \multirow{3}{*}{$\begin{array}{l}\text { Periapical pathosis } \\
\text { (on radiographs) without } \\
\text { symptoms and/or additional } \\
\text { problems }\end{array}$} & $\begin{array}{l}\text { In teeth without root canal filling: endodontic } \\
\text { treatment and/or apexification }\end{array}$ & $\begin{array}{l}\text { In teeth without root canal filling: endodontic } \\
\text { treatment }\end{array}$ \\
\hline & \multirow{2}{*}{$\begin{array}{l}\text { In teeth with root canal filling: } \\
\text { endodontic re-treatment, } \\
\text { apexification, or tooth extraction } \\
\text { (needed in case of pre-radiotherapy } \\
\text { time limitations) }\end{array}$} & $\begin{array}{l}\text { In teeth with root canal filling: } \\
\text { endodontic re-treatment, } \\
\text { apexification, or tooth extraction }\end{array}$ \\
\hline & & $\begin{array}{l}\text { Treatment can be postponed until after } \\
\text { radiotherapy }\end{array}$ \\
\hline \multirow{2}{*}{$\begin{array}{l}\text { Extensive periapical pathosis } \\
\text { (on radiographs) combined } \\
\text { with periodontal disease, in } \\
\text { afunctional teeth or with } \\
\text { symptoms }\end{array}$} & \multirow[t]{2}{*}{ Tooth extraction } & $\begin{array}{l}\text { In teeth without root canal filling: endodontic } \\
\text { treatment combined with initial periodontal } \\
\text { treatment }\end{array}$ \\
\hline & & $\begin{array}{l}\text { In teeth with root canal filling: } \\
\text { endodontic re-treatment, } \\
\text { apexification, or tooth extraction } \\
\text { depending on the prognosis }\end{array}$ \\
\hline $\begin{array}{l}\text { Avital pulp with symptoms } \\
\quad \text { without periapical } \\
\text { radiolucency on radiographs }\end{array}$ & $\begin{array}{l}\text { Endodontic treatment or tooth extraction } \\
\text { (which might be necessary in case of } \\
\text { pre-radiotherapy time limitations) }\end{array}$ & $\begin{array}{l}\text { Endodontic treatment or tooth extraction } \\
\text { depending on the prognosis }\end{array}$ \\
\hline $\begin{array}{l}\text { Avital pulp without symptoms } \\
\text { and without periapical } \\
\text { radiolucency on radiographs }\end{array}$ & $\begin{array}{l}\text { Endodontic treatment or tooth extraction } \\
\text { (needed in case of pre-radiotherapy time } \\
\text { limitations) }\end{array}$ & $\begin{array}{l}\text { Endodontic treatment } \\
\text { (which can be postponed until after } \\
\text { radiotherapy) }\end{array}$ \\
\hline \multirow{2}{*}{$\begin{array}{l}\text { Periodontal disease with: Pockets } \\
\quad 4-5 \mathrm{~mm}\end{array}$} & Initial periodontal therapy & Initial periodontal therapy \\
\hline & Tooth extraction & Initial periodontal therapy \\
\hline Pockets $\geq 6 \mathrm{~mm}$ & \multirow[t]{2}{*}{ Tooth extraction } & \multirow[t]{2}{*}{ Only recession requires no treatment } \\
\hline $\begin{array}{l}\text { Gingival recessions } \\
\quad \geq 6 \mathrm{~mm}\end{array}$ & & \\
\hline \multirow{2}{*}{$\begin{array}{l}\text { Impacted teeth or roots fully } \\
\text { covered by bone without } \\
\text { radiographic abnormalities }\end{array}$} & No treatment & \multirow[t]{2}{*}{ No treatment } \\
\hline & $\begin{array}{l}\text { If problems are expected in the future: } \\
\text { tooth extraction }\end{array}$ & \\
\hline \multirow{2}{*}{$\begin{array}{l}\text { Impacted teeth or roots not fully } \\
\text { covered by bone or with } \\
\text { radiographic abnormalities } \\
\text { (e.g., cysts, apical } \\
\text { radiolucency) }\end{array}$} & \multirow[t]{2}{*}{ Tooth extraction } & $\begin{array}{l}\text { No treatment or, in case of symptoms, surgical } \\
\text { removal }\end{array}$ \\
\hline & & $\begin{array}{l}\text { Roots with periapical radiolucency } \\
\text { might be worth preserving by } \\
\text { endodontic treatment and restoration } \\
\text { (which can be postponed until after } \\
\text { radiotherapy) }\end{array}$ \\
\hline Cysts & Surgical removal & Surgical removal \\
\hline $\begin{array}{l}\text { Internal or external root } \\
\text { resorption }\end{array}$ & Tooth extraction & $\begin{array}{l}\text { Endodontic treatment or tooth extraction } \\
\text { depending on the progosis }\end{array}$ \\
\hline
\end{tabular}

${ }^{\mathrm{a}}$ If an irradiated patient needed treatment, radiation fields were always verified with the department of Radiation Oncology, and depending on the dose in the specific region where treatment was needed, antibiotic prophylaxis was given to the patient

\section{Results}

\section{Demographics}

Between May 2011 and May 2013, 56 patients met the inclusion criteria (Fig. 1). Follow-up ranged from 11 to 27 months, with a median of 24 [22; 24] months (Fig. 2). Demographics, clinical characteristics, and baseline dental data of all patients are summarized in Table 3.

After dental screening and pre-radiation treatment of foci, $5 / 56$ patients needed a full mouth clearance (Fig. 1). Results on oral sequelae during follow-up are therefore based on the remaining 51 dentate patients. Results on dental screening and bone healing problems are based on the original 56 patients.

\section{Dental screening and treatment of oral foci}

Out of 56 dentate patients, $44(79 \%)$ had 1 or more oral foci at dental screening (Fig. 3). Baseline periodontal condition was healthy (no pockets) in 3 patients. Pocket depths of 4-5 and $\geq 6 \mathrm{~mm}$ were found in 25 and 28 patients, respectively. Thus, $53 / 56$ patients $(95 \%)$ had periodontal disease to some extent at baseline. Median pre-treatment PISA was $349 \mathrm{~mm}^{2}$ [131; 863] (Table 3). 


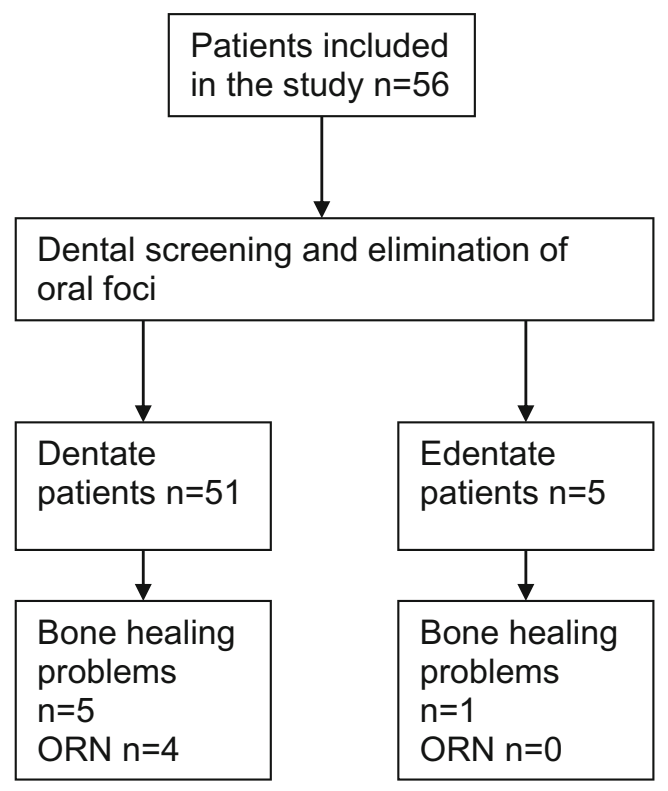

Fig. 1 Flow chart of included patients showing dentate and edentate patients

Pre-radiotherapy dental extractions were needed in 43 patients, viz., for 1 patient with no pockets, in 15 patients with pockets $4-5 \mathrm{~mm}$, and 27 in patients with pockets $\geq 6 \mathrm{~mm}$. Five patients $(11 \%)$ needed full mouth clearance: 4 patients had generalized severe periodontitis with pockets $\geq 6 \mathrm{~mm}$, and 1 patient never visited a dentist because of anxiety. A median of seven teeth $[2 ; 10]$ were extracted per patient. One patient had a dental cyst that was surgically removed. After focus elimination, the periodontal condition was healthy in 3 patients, while 48 dentate patients had remaining pockets of 4-5 mm.

\section{Oral sequelae during follow-up}

\section{Oral hygiene and fluoride prophylaxis}

All dentate patients were instructed to brush their teeth daily and to use fluoride gel every other day during follow-up. Comparing baseline and 2 years of follow-up, plaque scores reduced from a median of 50 to $30 \%(p=0.016)$ and bleeding scores from 30 to $10 \%(p=0.027)$.

\section{Post-radiotherapy periodontal health}

Post-radiotherapy, 12/51 dentate patients (24\%) had progression of periodontal pocket depth (4-5 $\mathrm{mm}$ pockets deepened) and/or developed new periodontal pockets $(\geq 4 \mathrm{~mm}$ on a site that was $\leq 3 \mathrm{~mm}$ before). Eight out of these 12 patients needed tooth extraction after dental screening before radiation because of pockets $\geq 6 \mathrm{~mm}$, and all 12 had remaining pockets of $4-5 \mathrm{~mm}$ (not considered as oral foci that needed extraction) before the onset of radiotherapy.

PISA scores decreased significantly during follow-up from $349 \mathrm{~mm}^{2}[131 ; 863]$ at baseline to $225 \mathrm{~mm}^{2}[139 ; 408]$ $(p=0.006)$ and $149 \mathrm{~mm}^{2}[77 ; 357](p=0.003$, Table 3$)$ at 6 months and 2 years follow-up, respectively, probably due to elimination of oral foci and improved oral hygiene.

\section{Post-radiotherapy tooth extractions}

Six patients $(12 \%)$ needed one to three post-radiotherapy tooth extractions because of deep dental caries $(n=4)$ or periodontal disease $(n=2)$.
Fig. 2 Kaplan Meier plot of follow-up in months. Nine patients dropped out before the end of the study: two were lost to follow-up, two patients died, and five patients were diagnosed with metastatic or recurrent disease and declined health care
Follow-up

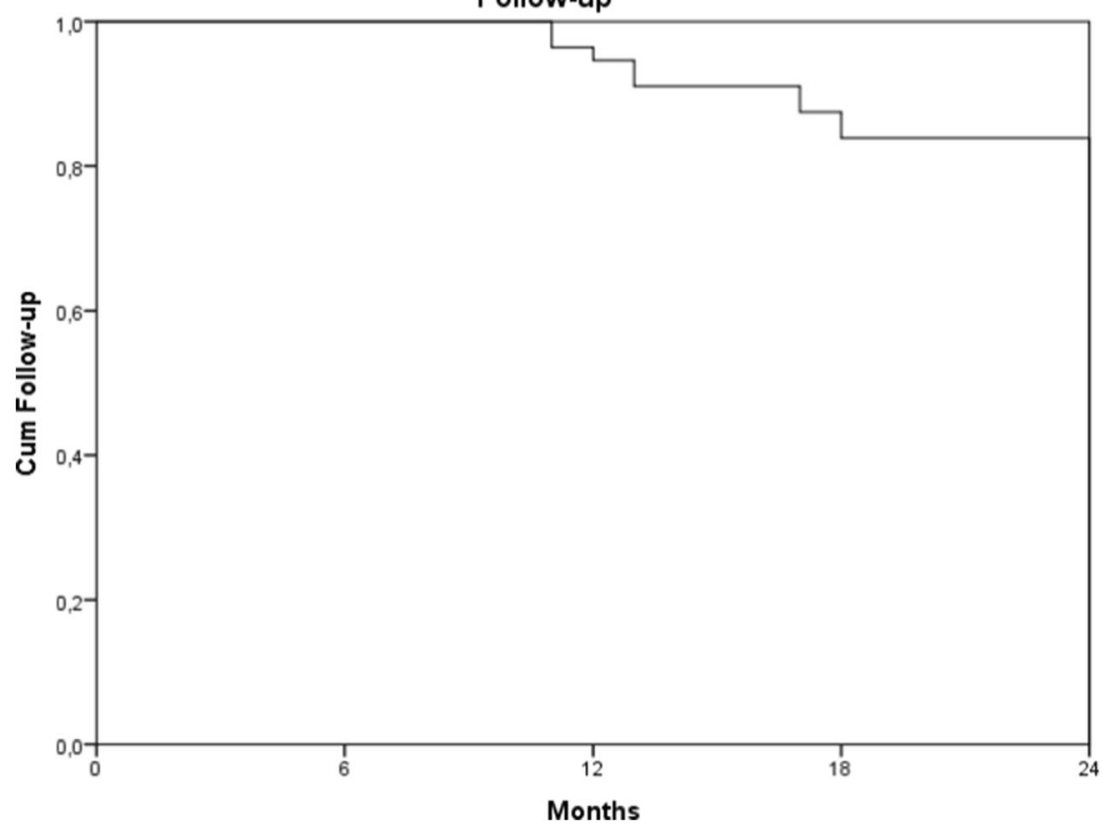


Table 3 Demographics, clinical characteristics, and baseline dental data of the study group $(n=56)$

\begin{tabular}{|c|c|c|c|c|}
\hline & Variable & Category & $\begin{array}{l}\text { Number of patients } \\
\text { dentate during follow-up }\end{array}$ & $\begin{array}{l}\text { Number of patients } \\
\text { edentate during follow-up }\end{array}$ \\
\hline & & & Total $n=51$ & Total $n=5$ \\
\hline \multirow[t]{2}{*}{ Demographics } & Age, years & Mean (SD) & $59(8.5)$ & $62(5.4)$ \\
\hline & Gender & Male/Female & $32 / 19$ & $4 / 1$ \\
\hline \multirow{26}{*}{$\begin{array}{l}\text { Clinical } \\
\text { characteris- } \\
\text { tics }\end{array}$} & Tumor site & Oral cavity & 25 & 1 \\
\hline & & Oropharynx & 26 & 4 \\
\hline & T-classification & $\mathrm{T} 1$ & 10 & 1 \\
\hline & & $\mathrm{T} 2$ & 17 & 2 \\
\hline & & T3 & 6 & 0 \\
\hline & & $\mathrm{T} 4$ & 17 & 2 \\
\hline & & Not reported & 1 & 0 \\
\hline & $\mathrm{N}$-classification & No & 17 & 1 \\
\hline & & N1 & 7 & 0 \\
\hline & & $\mathrm{N} 2$ & 25 & 4 \\
\hline & & N3 & 1 & 0 \\
\hline & & Not reported & 1 & 0 \\
\hline & $\begin{array}{l}\text { Cumulative } \\
\text { IMRT dose }\end{array}$ & Median [IQR] & $70[66-70]$ & $70[70-70]$ \\
\hline & $\begin{array}{l}\text { Frequency of } \\
\text { IMRT }\end{array}$ & 5/week & 42 & 3 \\
\hline & & 6/week & 9 & 2 \\
\hline & Primary IMRT & & 10 & 1 \\
\hline & $\begin{array}{l}\text { Postoperative } \\
\text { IMRT }\end{array}$ & & 14 & 0 \\
\hline & $\begin{array}{l}\text { Primary } \\
\text { CHIMRT }\end{array}$ & & 17 & 4 \\
\hline & $\begin{array}{l}\text { Postoperative } \\
\text { CHIMRT }\end{array}$ & & 10 & 0 \\
\hline & $\begin{array}{l}\text { Chemotherapy } \\
\text { type }\end{array}$ & Carboplatin/5-FU & 18 & 4 \\
\hline & & Cisplatin & 7 & 0 \\
\hline & & Cetuximab & 2 & 0 \\
\hline & Wound closure & Primary & 9 & 0 \\
\hline & & Skin graft/flap & 15 & 0 \\
\hline & $\begin{array}{l}\text { Self-reported } \\
\text { smoking }\end{array}$ & $\begin{array}{l}\text { Yes/In the } \\
\text { past/No/NR }\end{array}$ & $16 / 17 / 17 / 1$ & $4 / 0 / 1 / 0$ \\
\hline & $\begin{array}{l}\text { Alcohol } \\
\text { consump- } \\
\text { tion }\end{array}$ & Yes/No & $40 / 11$ & $3 / 2$ \\
\hline \multirow[t]{5}{*}{$\begin{array}{l}\text { Baseline } \\
\text { dental data }\end{array}$} & $\begin{array}{l}\text { Number of } \\
\text { teeth }\end{array}$ & Median [IQR] & 24 [18-27] & 11 [8.5-17] \\
\hline & Plaque score & Median [IQR] & 50 [25-75] & $70[45-80]$ \\
\hline & Bleeding score & Median [IQR] & $30[20-60]$ & $70[33-95]$ \\
\hline & PISA & Median [IQR] & 349 [131-863] & 533 [170-1509] \\
\hline & DMFS & Median [IQR] & $77[60-102]$ & $118[88-120\}$ \\
\hline
\end{tabular}

$S D$ standard deviation, IQR inter quartile range, IMRT intensity modulated radiation therapy, CHIMRT intensity modulated radiation therapy with chemotherapy, DMFS decayed missing filled surfaces. The range of scores is 0 $128, N R$ not reported

${ }^{a}$ After dental screening and pre-radiation treatment of oral foci, five patients needed a full mouth clearance

\section{Post-radiotherapy dental caries}

Out of 51 dentate patients, $13(25 \%)$ developed 1 or more carious lesions.

\section{Post-radiotherapy periapical pathosis}

Out of 51 patients, 3 patients (6\%) developed deep dental caries with periapical pathosis during follow-up. Endodontic treatment or tooth extraction was performed.

\section{Post-radiotherapy bone healing problems and ORN}

None of the 3 patients without periodontal pockets at baseline developed bone healing problems or ORN during 2-year follow-up.

Bone healing problems were observed in 10 out of 56 patients (18\%) in the mandible: 3 patients were diagnosed with delayed wound healing after pre-radiotherapy tooth extraction, 3 with lingual mandibular sequestration (unrelated to tooth extraction), and 4 with ORN (more details below). Of 


\section{ORAL FOCI OF INFECTION AT DENTAL SCREENING}

IN 56 PATIENTS

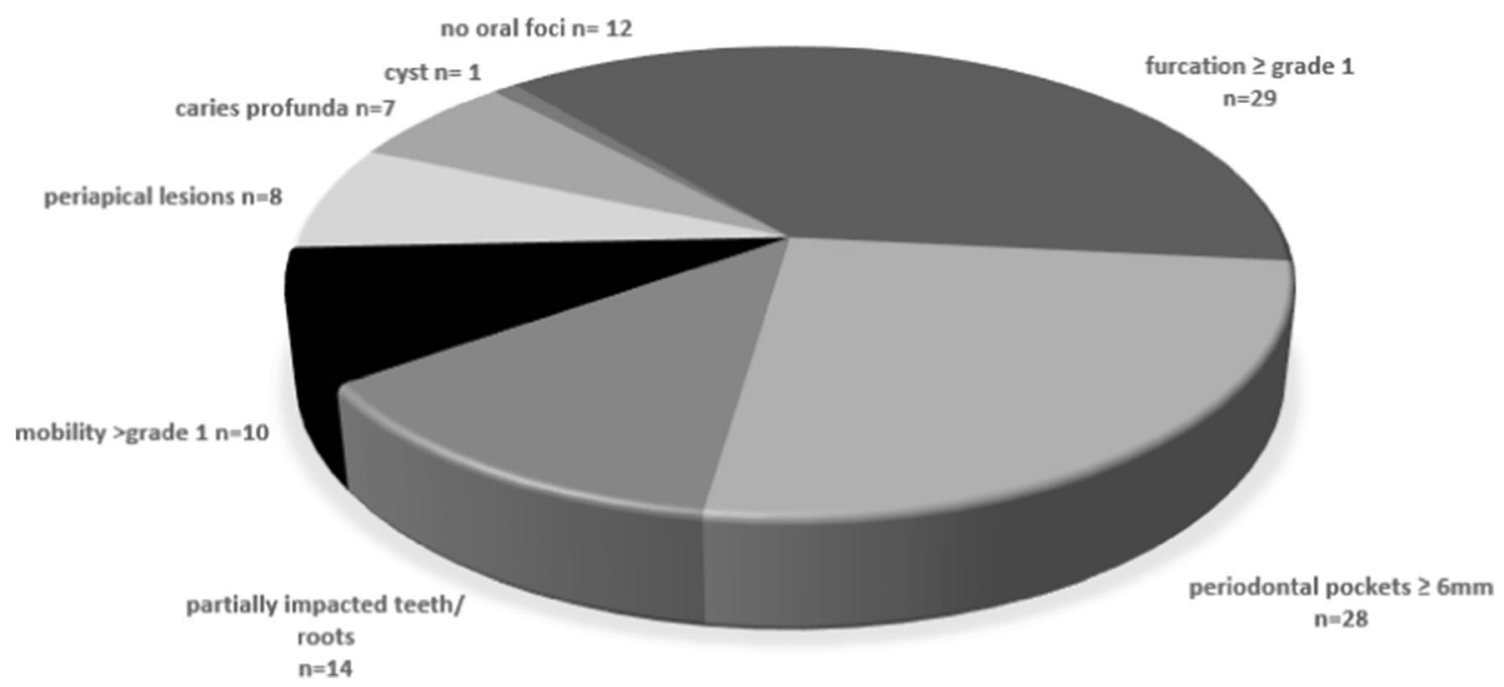

Fig. 3 Oral foci were found in 44 out of 56 patients. Since patients were occasionally diagnosed with more than one oral focus, the sum of the numbers exceeds 44. Patients had one to six oral foci with a mean of 2.3 foci per patient $(\mathrm{SD}=1.1)$

these 10 patients, 1 patient developed bone healing problems after pre-radiotherapy full mouth clearance. The other 9 patients had teeth left after elimination of oral foci and during the 2 years of follow-up.

In the group of patients with baseline periodontal pockets $\geq 6 \mathrm{~mm}(n=28), 5$ developed bone healing problems, not yet diagnosed as ORN, during follow-up (19\%) and 1 patient $(4 \%)$ in the group with pocket depths of 4-5 $\mathrm{mm}$ at baseline $(n=25)$. No increased risk for developing bone healing problems was found in patients with periodontal pockets $\geq 6 \mathrm{~mm}$ at baseline compared to patients with pockets $<6 \mathrm{~mm}$ at baseline, although there was strong tendency pointing in this direction $(p=0.084)$.

Of the 28 patients with periodontal pockets $\geq 6 \mathrm{~mm}$ at baseline, 2 developed ORN (7\%) as well as in 2 out of 25 patients with pockets $<6 \mathrm{~mm}$ at baseline (8\%). Therefore in our study, no increased risk for developing ORN was found in patients with periodontal pockets $\geq 6 \mathrm{~mm}$ at baseline compared to patients with pockets $<6 \mathrm{~mm}$ at baseline $(p=1.000)$.

ORN developed in 1 patient, 3 months after completion of postoperative IMRT in an area where a severely periodontal compromised mandibular molar was removed before radiotherapy. In a second patient, ORN developed, 7 months after postoperative CHIMRT. Extended caries developed in the most distal mandibular molar in this patient. Endodontic treatment was impossible to perform and the molar was extracted post-radiotherapy resulting in a non-healing socket and eventually ORN. This patient was free of oral foci at baseline, but had pockets of $4-5 \mathrm{~mm}$ at baseline.

Idiopathic ORN of the angle of the mandible resulting in a pathologic fracture developed in 1 patient 2 months after
CHIMRT had ended. This patient was free of periodontal disease during follow-up. In another patient, ORN was unrelated to pre- or post-radiotherapy tooth extractions, as it was observed 2 months after postoperative IMRT in the transplanted fibula bone used for reconstruction of the mandible. The patient had post-radiotherapy surgery, however, to remove reconstruction plates. This patient had periodontal pockets $4-5 \mathrm{~mm}$ at baseline.

Many factors might influence development of bone healing problems after radiotherapy. Patients with $(n=10)$ and without $(n=46)$ bone healing problems were compared for number of teeth extracted after dental screening $(p=0.052)$, number of teeth at dental screening $(p=0.357)$, T-stage $(p=0.093)$, having diabetes $(p=0.186)$, smoking at baseline $(p=0.755)$, drinking alcohol at baseline $(p=0.275)$, baseline plaque $(p=0.949)$, bleeding $(p=0.355)$ and PISA scores ( $p=0.072)$, and having periodontal pockets $\geq 4 \mathrm{~mm}$ ( $p=0.406)$ or $\geq 6 \mathrm{~mm}$ at dental screening $(p=0.163)$.

\section{Multiple logistic regression analysis}

Multiple logistic regression analysis showed that of the variables assessed (see section on statistical analysis), only the PISA score predicted a higher risk on developing ORN or bone healing problems.

\section{Comparison historical control group}

Comparison with historical controls [2], on baseline, showed no difference for the presence of oral foci (75 vs. 79\%;

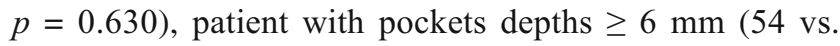


$50 \% ; p=0.668$ ), and extractions (average of 7.7 extracted teeth vs. $7.0 ; p=0.266)$. In this study, $7 \%$ of the patients developed ORN compared to $11 \%$ of the historical controls $(p=0.424)$.

\section{Discussion}

This study showed that patients with periodontal disease before IMRT/CHIMRT are prone to develop bone healing problems post-radiotherapy. The assessed protocol for elimination of oral foci pre-IMRT was compared to historical controls with conventional radiotherapy [2]; the protocol was equally effective for patients treated with IMRT/CHIMRT. Postradiotherapy oral and dental morbidity seen in IMRT/ CHIMRT patients is comparable to that seen in patients treated with conventional radiotherapy.

\section{Periodontal inflamed surface area}

The relationship between periodontal disease and bone healing problems is supported by our finding that baseline PISA scores predicted a higher risk on developing ORN or bone healing problems. Presence of periodontal pockets $\geq 6 \mathrm{~mm}$ at dental screening was different between patients with and without bone healing problems, although not significant. There seems to be a strong trend, however, and our study may have been underpowered to find a significant difference. The correlation of PISA with ORN deserves further study.

\section{Oral foci}

Compared to our retrospective study [2] that included 80 patients subjected to conventional radiotherapy (mean follow-up 26 months), a comparable percentage of patients presented with oral foci. Again, oral foci consisted mainly of periodontal disease, which is comparable to the percentage of patients with periodontal problems $(68 \%)$ in the small study of Bueno et al. [22]. Approximately $10 \%$ of Dutch adults have severe periodontal disease [23]. Apparently, poor periodontal health is more common among HNC patients [2, 4, 24, 25] and might be a major cause of bone-related oral sequelae postradiotherapy.

\section{Bone healing problems and ORN}

Bone healing problems were observed in 10/56 patients $(18 \%)$. We diagnosed 5 patients with delayed wound healing and 1 with lingual mandibular sequestration, which was not defined as ORN because healing occurred within 3 months after minimally invasive surgery (sequestrectomy). Immediate surgical intervention in case of exposed bone, as done in our hospital, may result in a more rapid healing compared to observation.

ORN was reported in $7 \%$ of our patients after IMRT compared to $11 \%$ in our retrospective three-dimensional conformal radiation therapy (3D-CRT) study [2]. The prevalence of ORN as reported in the literature is highly variable [7] and the reported outcomes on occurrence of ORN after IMRT are limited. Our findings suggest a reduced rate of ORN following the clinical introduction of IMRT [26-28]. It has been suggested, however, that the latency time to develop jaw complications after IMRT is longer. Nevertheless, after 3 years, the risk of developing jaw complications appears to be equal to that for non-IMRT treatment [29]. Nabil et al. [7] suggested a median/mean follow-up of $>3$ years, since $90 \%$ of ORN cases were reported within 3 years after radiotherapy. Our median follow-up was shorter than in the studies referred to, and more cases of ORN may develop in our cohort in the future. However, all cases of ORN in this study occurred in the first 7 months after IMRT.

Studer et al. [26] reported 5 cases of ORN in 304 patients $(1.6 \%)$ with oropharyngeal or oral cavity carcinoma treated with IMRT, with a follow-up between 5 and 86 months [26]. Gomez et al. [28] included 168 patients with a follow-up between 0.8 and 89.6 months; they reported a low incidence of ORN $(1 \%)$. However, $54 \%$ of the included patients in the latter study had a tumor located outside the oral cavity or oropharynx, resulting in a lower radiation dose to the jaws, which might be accompanied by a lower incidence of ORN. Both studies did not report how many patients received postoperative or primary IMRT, which may have influenced the outcomes on ORN since it is a known risk factor [8]. A complete lack of ORN was reported by Ben-David et al. [27]. They suggested that the reduction in the ORN rates could be attributed to more conformal dose distributions and to better prophylactic care and ongoing dental care.

Our oral care protocol was similar for our retrospective and prospective study, although it was more strictly executed prospectively, with only 1 patient that was not treated according to protocol compared to 15 patients in the retrospective study [2]. Those 15 patients received pre-radiotherapy initial periodontal therapy for teeth with pockets $\geq 6 \mathrm{~mm}$, instead of tooth extraction, and they were particularly at risk of developing ORN. The improved implementation of the dental screening protocol may have decreased our ORN prevalence, as suggested by others [27], and this might explain the weaker relationship between periodontal disease and ORN found in the present study compared to the retrospective study [2]. Nevertheless, periodontal disease, derived as PISA scores, is still the only factor that we found to be associated with bone healing problems.

Periodontal treatment might have a short-term (6 months) positive effect on periodontal breakdown [22], but the present study (median follow-up 24 months) showed that progression 
of periodontal pocket depth was frequently observed after IMRT (24\%). This percentage is even higher than the $18 \%$ reported in the retrospective study [2].

In our study on oral microflora [30], we found an almost immediate effect after the elimination of oral foci, with a decrease of periodontal pathogens. However, rather high percentages of periodontal pathogens were still present in our HNC patients 1 year after IMRT and may be involved in progression of pocket depths.

\section{Conclusion}

This study showed that patients with severer periodontal disease present before IMRT/CHIMRT, i.e., a higher PISA, were more prone to develop bone healing problems post-radiotherapy. Furthermore, it was shown that post-radiotherapy oral and dental morbidity seen in IMRT/CHIMRT patients was comparable to that of patients treated with three-dimensional conformal radiation therapy under the condition of preradiation screening and treatment of oral foci.

\section{Acknowledgements The authors thank Charles Frink for proofreading.}

\section{Compliance with ethical standards}

Conflict of interest J.M. Schuurhuis declares, on behalf of all authors, that we have no conflict of interest. We have full control of all primary data and agree to allow the journal to review the data if requested.

Open Access This article is distributed under the terms of the Creative Commons Attribution-NonCommercial 4.0 International License (http:// creativecommons.org/licenses/by-nc/4.0/), which permits any noncommercial use, distribution, and reproduction in any medium, provided you give appropriate credit to the original author(s) and the source, provide a link to the Creative Commons license, and indicate if changes were made.

\section{References}

1. Nabil S, Samman N (2011) Incidence and prevention of osteoradionecrosis after dental extraction in irradiated patients: a systematic review. Int J Oral Maxillofac Surg 40:229-243

2. Schuurhuis JM, Stokman MA, Roodenburg JLN, Reintsema H, Langendijk JA, Vissink A, Spijkervet FKL (2011) Efficacy of routine pre-radiation dental screening and dental follow-up in head and neck oncology patients on intermediate and late radiation effects. A retrospective evaluation. Radiother Oncol 101:403-409

3. Schuurhuis JM, Stokman MA, Witjes MJ, Dijkstra PU, Vissink A, Spijkervet FK (2015) Evidence supporting pre-radiation elimination of oral foci of infection in head and neck cancer patients to prevent oral sequelae. A systematic review. Oral Oncol 51:212-220

4. Epstein JB, Lunn R, Le N, Stevenson-Moore P (1998) Periodontal attachment loss in patients after head and neck radiation therapy. Oral Surg Oral Med Oral Pathol Oral Radiol Endod 86:673-677
5. Marx RE (1983) A new concept in the treatment of osteoradionecrosis. J Oral Maxillofac Surg 41:351-357

6. Spijkervet F, Brennan M, Peterson D, Witjes M, Vissink A (2016) Research Frontiers:Oral Toxicities of Cancer Therapies. Osteoradionecrosis (ORN) of the Jaws. JNCI Submitted

7. Nabil S, Samman N (2012) Risk factors for osteoradionecrosis after head and neck radiation: a systematic review. Oral Surg Oral Med Oral Pathol Oral Radiol 113:54-69

8. Lee IJ, Koom WS, Lee CG, Kim YB, Yoo SW, Keum KC, Kim GE, Choi EC, Cha IH (2009) Risk factors and dose-effect relationship for mandibular osteoradionecrosis in oral and oropharyngeal cancer patients. Int J Radiat Oncol Biol Phys 75:1084-1091

9. Katsura K, Sasai K, Sato K, Saito M, Hoshina H, Hayashi T (2008) Relationship between oral health status and development of osteoradionecrosis of the mandible: a retrospective longitudinal study. Oral Surg Oral Med Oral Pathol Oral Radiol Endod 105: 731-738

10. Sennhenn-Kirchner S, Freund F, Grundmann S, Martin A, Borgvon Zepelin M, Christiansen H, Wolff HA, Jacobs HG (2009) Dental therapy before and after radiotherapy - an evaluation on patients with head and neck malignancies. Clin Oral Investig 13: 157-164

11. Gregoire V, Langendijk JA, Nuyts S (2015) Advances in radiotherapy for head and neck cancer. J Clin Oncol 33:3277-3284

12. Vissink A, Mitchell JB, Baum BJ, Limesand KH, Jensen SB, Fox PC, Elting LS, Langendijk JA, Coppes RP, Reyland ME (2010) Clinical management of salivary gland hypofunction and xerostomia in head-and-neck cancer patients: successes and barriers. Int J Radiat Oncol Biol Phys 78:983-991

13. Hansen HJ, Maritim B (2012) Bohle GC,3rd, lee NY, Huryn JM, Estilo CL. Dosimetric distribution to the tooth-bearing regions of the mandible following intensity-modulated radiation therapy for base of tongue cancer Oral Surg Oral Med Oral Pathol Oral Radiol 114:e50-e54

14. Jansma J, Vissink A, Spijkervet FK, Roodenburg JL, Panders AK, Vermey A, Szabo BG, Gravenmade EJ (1992) Protocol for the prevention and treatment of oral sequelae resulting from head and neck radiation therapy. Cancer 70:2171-2180

15. Nesse W, Abbas F, van der Ploeg I, Spijkervet FK, Dijkstra PU, Vissink A (2008) Periodontal inflamed surface area: quantifying inflammatory burden. J Clin Periodontol 35:668-673

16. Stokman MA, Burlage FR, Spijkervet FK (2012) The effect of a calcium phosphate mouth rinse on (chemo) radiation induced oral mucositis in head and neck cancer patients: a prospective study. Int J Dent Hyg 10:175-180

17. Jansma J, Vissink A, Bouma J, Vermey A, Panders AK, Gravenmade EJ (1992) A survey of prevention and treatment regimens for oral sequelae resulting from head and neck radiotherapy used in Dutch radiotherapy institutes. Int J Radiat Oncol Biol Phys 24:359-367

18. Jansma J, Vissink A, Gravenmade EJ, Visch LL, Fidler V, Retief DH (1989) In vivo study on the prevention of postradiation caries. Caries Res 23:172-178

19. Epstein JB, Rea G, Wong FL, Spinelli J, Stevenson-Moore P (1987) Osteonecrosis: study of the relationship of dental extractions in patients receiving radiotherapy. Head Neck Surg 10:48-54

20. Harris M (1992) The conservative management of osteoradionecrosis of the mandible with ultrasound therapy. Br J Oral Maxillofac Surg 30:313-318

21. Store G, Boysen M (2000) Mandibular osteoradionecrosis: clinical behaviour and diagnostic aspects. Clin Otolaryngol Allied Sci 25: 378-384

22. Bueno AC, Ferreira RC, Barbosa FI, Jham BC, Magalhaes CS, Moreira AN (2013) Periodontal care in patients undergoing radiotherapy for head and neck cancer. Support Care Cancer 21:969-975 
23. van Winkelhoff AJ, Winkel EG, Vandenbroucke-Grauls CM (2001) Periodontitis: a hidden chronic infection. Ned Tijdschr Geneeskd 145:557-563

24. Bonan PR, Lopes MA, Pires FR, Almeida OP (2006) Dental management of low socioeconomic level patients before radiotherapy of the head and neck with special emphasis on the prevention of osteoradionecrosis. Braz Dent J 17:336-342

25. Jham BC, Reis PM, Miranda EL, Lopes RC, Carvalho AL, Scheper MA, Freire AR (2008) Oral health status of 207 head and neck cancer patients before, during and after radiotherapy. Clin Oral Investig 12:19-24

26. Studer G, Glanzmann C, Studer SP, Gratz KW, Bredell M, Locher M, Lutolf UM, Zwahlen RA (2011) Risk-adapted dental care prior to intensity-modulated radiotherapy (IMRT). Schweiz Monatsschr Zahnmed 121:216-229

27. Ben-David MA, Diamante M, Radawski JD, Vineberg KA, Stroup C, Murdoch-Kinch CA, Zwetchkenbaum SR, Eisbruch A (2007) Lack of osteoradionecrosis of the mandible after intensity- modulated radiotherapy for head and neck cancer: likely contributions of both dental care and improved dose distributions. Int J Radiat Oncol Biol Phys 68:396-402

28. Gomez DR, Estilo CL, Wolden SL, Zelefsky MJ, Kraus DH, Wong RJ, Shaha AR, Shah JP, Mechalakos JG, Lee NY (2011) Correlation of osteoradionecrosis and dental events with dosimetric parameters in intensity-modulated radiation therapy for head-andneck cancer. Int J Radiat Oncol Biol Phys 81:e207-e213

29. Beadle BM, Liao KP, Chambers MS, Elting LS, Buchholz TA, Kian Ang K, Garden AS, Guadagnolo BA (2013) Evaluating the impact of patient, tumor, and treatment characteristics on the development of jaw complications in patients treated for oral cancers: a SEER-Medicare analysis. Head Neck 35:1599-1605

30. Schuurhuis J, Stokman M, Witjes M, Langendijk J, Van Winkelhoff A, Vissink A, Spijkervet F (2016) Head and neck intensity modulated radiation therapy leads to an increase of opportunistic oral pathogens. Oral Oncol 58:32-40 